\section{'UENF 506-11': a new maize cultivar for the North and Northwest of Rio de Janeiro State}

\author{
Messias Gonzaga Pereira ${ }^{1}$, Ana Paula Candido Gabriel Berilli², \\ Roberto dos Santos Trindade ${ }^{3}$, Geovana Cremonini Entringer ${ }^{1}$, \\ Pedro Henrique Araújo Diniz Santos ${ }^{1}$, Julio Cesar Fiorio \\ Vettorazzi ${ }^{{ }^{*}}$ and Keila Silva da Cunha Galvão ${ }^{4}$
}

\begin{abstract}
The intervarietal hybrid 'UENF 506-11' was derived from full-sib maize families in the $11^{\text {th }}$ cycle of reciprocal recurrent selection. It produces a grain yield of 7.57 tons ha $^{-1}$, and is recommended for cultivation in the North and Northwest regions of the Rio de Janeiro State.
\end{abstract}

Keywords: Zea mays L., reciprocal recurrent selection, cultivar, plant breeding.

\section{INTRODUCTION}

Maize (Zea mays L.) is a cereal of great economic and social importance, cultivated in almost all agricultural regions of the world and used in human and animal nutrition and, more recently, as a source of biofuel. Brazil is the third largest producer in the world, with a production in the year 2017 of 97 million tons, which is surpassed only by the United States and China (FAOSTAT, 2019). Much of the yield potential of this crop in the country is the result of significant advances in breeding programs, which have progressively improved agronomic traits related to grain yield, disease resistance and adaptability to adverse conditions.

For the state of Rio de Janeiro, no agricultural zoning indicates which cultivars are best planted. Maize is grown almost exclusively by small farmers with low technological input, generally without irrigation, for grain and silage production. Mostly, the farmers grow open-pollinated varieties and hybrids developed for other regions of Brazil.

Historically, until the 1980s, the North and Northwest of Rio de Janeiro stood out as one of the largest sugarcane-producing regions of Brazil (Silva 2006). However, dwindling yields caused by a decline in natural soil fertility due to successive cultivation without nutrient replenishment and increased production costs, led to a decline in sugarcane farming in the region (Castro and Ribeiro 2010). In this context, considering the edaphoclimatic conditions of the North and Northwest of Rio de Janeiro, with an undulating plain relief, appropriate for a mechanized crop management, and for maize cultivation destined for grain as well as silage for livestock, the potential of maize is perceived as an important alternative of crop diversification for the region.

In 1996, the Universidade Estadual do Norte Fluminense Darcy Ribeiro (UENF) initiated a maize breeding program based on Full-sib Reciprocal
Crop Breeding and Applied Biotechnology

19: 141-144, 2019 Brazilian Society of Plant Breeding. Printed in Brazil http://dx.doi.org/10.1590/198470332019v19n1c20

\footnotetext{
*Corresponding author: E-mail: juliocesar.f.v@hotmail.com (DD ORCID: 0000-0002-3887-7735
}

Received: 02 October 2017 Accepted: 05 November 2018

\footnotetext{
${ }^{1}$ Universidade Estadual do Norte Fluminense Darcy Ribeiro, 28.013-602, Campos dos Goytacazes, RJ, Brazil ${ }^{2}$ Instituto Federal do Espírito Santo, 29.070910, Colatina, ES, Brazil ${ }^{3}$ Embrapa Milho e Sorgo, Núcleo de Recursos Genéticos e Geração de Cultivares (NRGC), Embrapa Milho e Sorgo, Rodovia MG 424, km 65, CEP: 35.701-970, Sete Lagoas, MG, Brazil. ${ }^{4}$ Instituto de Ensino Superior do Espirito Santo, 29.360-000, Castelo, ES, Brazil
} 
Recurrent Selection (FSRRS). The continuous progress of this breeding program has provided maize producers in the North and Northwest regions of Rio de Janeiro with hybrids with excellent agronomic response and adapted to the regional conditions. In 2000, this program released the inter-populational hybrid 'UENF 506-6' with superior agronomic performance over other cultivars, which has been successfully used by farmers (Tardin et al. 2007, Berilli et al. 2013).

The objective of this study was to describe the main traits of the intervarietal maize hybrid 'UENF 506-11', of the $11^{\text {th }}$ cycle of FSRRS.

\section{Pedigree and Breeding Method}

Two maize populations of different heterotic groups were used, one called CIMMYT and the other Piranão, of the heterotic groups "flint" and "dent", respectively. Both populations have the brachytic gene $\left(b r_{2}\right)$, introduced by backcrossing in a pre-breeding stage, resulting in short plant height. Both populations came from the Universidade Federal de Viçosa (UFV), where they undergone five cycles of FSRRS. As of the sixth cycle, selection was carried out at the UENF.

The FSRRS was described by Hallauer and Eberhart (1970). This methodology promotes the accumulation of favorable alleles within the involved populations and increases the combining ability among them, preserving the genetic variability among and within them (Reis et al. 2009).

\section{Field trials}

Field evaluations were performed from September to February in the growing seasons of 2009/2010, 2010/2011 and 2011/2012 at three locations: two in Campos dos Goytacazes - RJ and one in Itaocara - RJ, totaling nine environments. These nine constitute the environments where the VCU (Value for Cultivation and Use) trials were carried out. In all trials, a randomized complete block design with five replications was used. The experimental plots consisted of a single $4.0 \mathrm{~m}$ row, at a plant spacing of $0.2 \mathrm{~m}$ between plants and $1.0 \mathrm{~m}$ between rows.

Twenty-one genotypes of the FSRRS program of the UENF, seven of which were intervarietal hybrids between the CIMMYT and Piranão populations and the respective parent populations, were evaluated. In addition, seven control genotypes were evaluated: two commercial hybrids ('AG 1051' and 'BM 2202'), an intervarietal hybrid ('Fortaleza' versus CIMMYT 8), three commercial varieties ('BR 106', 'Fortaleza' and 'Sol da Manhã'), and the Composto Caboclo $b r_{2}$. For the sake of simplicity, only the results of the registered intervarietal hybrid ('UENF 506-11') and the controls used in the experiment were presented (Table 1).

The crop management at the different locations and in all trials was applied as recommended for maize (Fancelli and Dourado Neto 2000). During the experimental period, seven maize descriptors and nine morpho-agronomic traits were evaluated, according to the minimum requirements for registry in the national cultivar registration system (MAPA 2019). The plots were harvested by hand and the grain yield was weighed considering a grain moisture content of $13 \%$.

Table 1. Summary of analysis of variance with the respective mean squares, coefficients of experimental variation (CV), means of the evaluated traits and coefficient of genotypic determination $\left(\mathrm{H}^{2}\right)$, between 2009 and 2012 in three environments.

\begin{tabular}{|c|c|c|c|c|c|c|c|c|c|c|}
\hline \multirow{2}{*}{ SV } & \multirow{2}{*}{ df } & \multicolumn{9}{|c|}{ Mean squares } \\
\hline & & STAND & NLP & DFL & NE & EW & GW & HW & W100 & GY \\
\hline$B / E$ & 36 & 7.33 & 5.89 & 5.39 & 27.93 & 0.88 & 0.64 & 825.97 & 664.53 & 3.21 \\
\hline Block (B) & 4 & 12.5 & 8.18 & 13.79 & 44.14 & 0.90 & 1.20 & 1213.34 & 320.78 & 5.99 \\
\hline $\mathrm{B} \times \mathrm{E}$ & 32 & 6.68 & 5.6 & 4.34 & 25.91 & 0.88 & 0.57 & 777.55 & 707.50 & 2.86 \\
\hline Genotype (G) & 4 & $285.19 * *$ & $113.49 * *$ & $155.44^{* *}$ & $576.64 * *$ & $36.5^{* *}$ & $33.14 * *$ & $29211.8 * *$ & $12463.20 * *$ & $163.74^{* *}$ \\
\hline Environment $(E)$ & 8 & $97.47 * *$ & $76.90 * *$ & $424.55^{* *}$ & $220.75^{* *}$ & $13.26^{* *}$ & $9.98 * *$ & $5252.86 * *$ & $11634.98^{* *}$ & $49.34 * *$ \\
\hline Mean & & 23.23 & 2.4 & 62.99 & 25.27 & 3.61 & 3.02 & 744.29 & 304.34 & 6.72 \\
\hline CV (\%) & & 16.16 & 123.59 & 4.49 & 24.81 & 31.43 & 22.77 & 4.9 & 7.75 & 22.78 \\
\hline $\mathrm{H}^{2}$ & & 0.95 & 0.92 & 0.95 & 0.93 & 0.96 & 0.98 & 0.95 & 0.95 & 0.98 \\
\hline
\end{tabular}

STAND: Number of plants per experimental unit; NLP: Number of lodged plants; DFL: Days until flowering; NE: Number of ears; EW: Ear weight; GW: Grain weight; HW: Hectoliter weight; W1000: 1000-grain weight; GY: Grain yield (tons ha ${ }^{-1}$ ). * and ${ }^{* *}$ Significant at 5 and $1 \%$ by the F test, respectively. 


\section{Statistical Analyses}

An individual ANOVA of the morpho-agronomic traits was performed for each environment (data not shown). The coefficients of variation for all environments were found to be lower than $20 \%$, so the homogeneity of the residual variances was evaluated by the $\mathrm{F}$ test (Hartley 1950). The combined analysis of experiments was performed since the ratio between the highest and the lowest residual $\mathrm{F}$ for the evaluated environments was less than seven (Table 1). Tukey mean test at $5 \%$ probability was applied based on the mean of the tested environments. Software GENES (Cruz 2013) was used for all statistical analyses. For the genotype $x$ environment interaction for the trait grain yield, significance at $5 \%$ probability was observed, but since these environments were close together and in view of the excellent performance of hybrid 'UENF 506-11' in the different environments, there was no need to register different hybrids for these regions. Thus, the overall means were considered for the mean test comparisons.

\section{Agronomic Performance}

In three growing seasons at three locations the grain yield of the inter-population hybrid 'UENF 506-11' was only surpassed by hybrid 'AG1051' (Table 2). The Tukey mean test indicated that the intervarietal hybrid 'UENF 506-11' had a similar grain yield to the commercial hybrid 'BM 2202' and higher than that of the commercial varieties 'BR 106' and 'Sol da Manhã', and was only lower than that of the commercial hybrid 'AG 1051'.
Table 2. Yield of 'UENF 506-11' compared to the mean of four controls by Tukey test $(P>0.05)$ in evaluations between 2009 and 2012 in three environments

\begin{tabular}{lc}
\hline Cultivars & Grain yield (tons ha ${ }^{-1}$ ) \\
\hline AG 1051 & $8.86 \mathrm{a}$ \\
'UENF 506-11' & $7.57 \mathrm{~b}$ \\
BM 2202 & $7.23 \mathrm{~b}$ \\
BR 106 & $6.14 \mathrm{c}$ \\
SOL DA MANHÃ & $3.78 \mathrm{~d}$ \\
\hline MSD & 0.69 \\
\hline MSD = Minimal Significant Difference.
\end{tabular}

Table 3. Descriptive statistics for eight agronomic traits of three maize genotypes evaluated in tests of value for cultivation and use (VCU), in the growing seasons of 2009, 2010 and 2012, at three locations

\begin{tabular}{|c|c|c|c|c|c|}
\hline & & \multicolumn{4}{|c|}{ Morpho-agronomics traits } \\
\hline & & Plant height & Ear height & Plant density & Ear index \\
\hline \multirow{8}{*}{ 'UENF 506-11' } & Mean & 2.07 & 1.27 & 24 & 1.2 \\
\hline & Upper limit & 2.63 & 2.25 & 30 & 1.6 \\
\hline & Lower limit & 1.44 & 0.80 & 17 & 0.4 \\
\hline & & Female flowering & Male flowering & 1000-grain weight (g) & Grain yield (t ha-1) \\
\hline & Mean & 64 & 64 & 314 & 7.57 \\
\hline & Upper limit & 71 & 75 & 380 & 11.56 \\
\hline & Lower limit & 59 & 58 & 250 & 1.78 \\
\hline & & Plant height & Ear height & Plant density & Ear index \\
\hline \multirow{8}{*}{ 'BM 2202' } & Mean & 1.85 & 0.99 & 25 & 1.1 \\
\hline & Upper limit & 2.31 & 1.33 & 41 & 1.5 \\
\hline & Lower limit & 1.41 & 0.54 & 18 & 0.5 \\
\hline & & Female flowering & Male flowering & 1000-grain weight (g) & Grain yield $\left(\mathrm{t} \mathrm{ha} \mathrm{a}^{-1}\right)$ \\
\hline & Mean & 59 & 60 & 296 & 7.24 \\
\hline & Upperlimit & 66 & 67 & 380 & 11.78 \\
\hline & Lower limit & 53 & 54 & 210 & 0.57 \\
\hline & & Plant height & Ear height & Plant density & Ear index \\
\hline \multirow{7}{*}{ 'BR 106' } & Mean & 1.94 & 1.07 & 24 & 1.1 \\
\hline & Upper limit & 2.38 & 1.80 & 29 & 1.8 \\
\hline & Lower limit & 1.25 & 0.65 & 20 & 0.3 \\
\hline & & Female flowering & Male flowering & 1000-grain weight (g) & Grain yield $\left(\mathrm{t} \mathrm{ha}^{-1}\right)$ \\
\hline & Mean & 59 & 61 & 304 & 6.15 \\
\hline & Upper limit & 62 & 65 & 360 & 11.56 \\
\hline & Lower limit & 53 & 54 & 248 & 1.08 \\
\hline
\end{tabular}




\section{Other Traits}

The main traits of hybrid 'UENF 506-11' were compared to the other cultivars used in the region and evaluated in the experiment (Table 3). Hybrid 'UENF 506-11' is appropriate for grain or silage production or for fresh consumption. The grain is classified as semi-hard and yellow/orange. The recommended cultivation period for the intervarietal hybrid is between September and February.

\section{Seed Production and Distribution}

The intervarietal hybrid 'UENF 506-11' was registered by the Ministry of Agriculture, Livestock and Supply - MAPA (no. 30595). Seeds are produced and commercialized by Rio Norte Sementes Company in partnership with UENF.

\section{REFERENCES}

Berilli APCG, Pereira MG, Trindade RS and Costa FR (2013) Response to the selection in the $11^{\text {th }}$ cycle of reciprocal recurrent selection among full-sib families of maize. Acta Scientiarum 35: 435-441.

Castro RAR and Ribeiro AC (2010) Relações de cooperação no aglomerado sucroalcooleiro fluminense: reflexões sobre o papel do recurso intangível no desenvolvimento regional. Agenda Social 4: 59-75.

Cruz CD (2013) Genes: a software package for analysis in experimental statistics and quantitative genetics. Acta Scientiarum Agronomy 35: $271-276$.

Fancelli AL and Dourado Neto D (2000) Produção de milho. Agropecuária, Guaíba, 360p.

FAOSTAT (2019) Food and Agriculture organization of the United Nations. Production quantities of Maize by country 2017. Available at: <http:// www.fao.org/faostat/en/\#data/QC/visualize>. Access in Marh, 2019.

Hallauer AR and Eberhart SA (1970) Reciprocal full-sib selection. Crop
Science 10: 315-316.

Hartley HO (1950) The maximum F-ratio as a short-cut teste for heterogeneity of variances. Biometrika 37: 308-312.

MAPA - Ministério da Agricultura, Pecuária e Abastecimento (2019). Valor de cultivo e uso. Available at: < http://sistemas.agricultura.gov.br/ snpc/cultivarweb/index.php>. Access in March, 2019.

Reis MC, Souza JC, Ramalho MAP, Guedes FL and Santos PHAD (2009) Progresso genético com a seleção recorrente recíproca para híbridos interpopulacionais de milho. Pesquisa Agropecuária Brasileira 44: 1667-1672.

Silva LC (2006) Reconfiguração do Norte Fluminense a partir dos anos 70: a chegada do petróleo e suas consequências na dinâmica de crescimento regional. Revista Plurais 1: 167-187.

Tardin FD, Pereira MG, Gabriel APC, Amaral Junior AT and Filho GAS (2007) Selection index and molecular markers in reciprocal recurrent selection in maize. Crop Breeding and Applied Biotechnology 7: 225-233. 